\title{
IN VITRO IMMUNOTOXICOLOGY - PRACTICAL APPLICATION
}

\author{
A. K. SIWICKI ${ }^{1.4}$, M. MORAND', M. STUDNICKA ${ }^{3}$ \\ ${ }^{1}$ Department of Epizootiology with Clinic of Infections Diseases, Faculty of Veterinary Medicine, \\ University in Olsztyn. Poland \\ ${ }^{2}$ Laboratoire Departemental d Analyses du Jura, Lons le Saunier. France \\ ${ }^{3}$ Department of Physiology and Toxicology, Catholic University Lublin. Poland
}

Received July, 1998

Accepted September, 1998

\begin{abstract}
Siwicki A. K., M. Morand, M. Studnicka: In vitro Immunotoxicology - Practical Application. Acta vet. Brno 1998. 67: 303-307.

The in vitro immunology is one of the most important directions in immunotoxicology. At present, many in vitro methods are used in control drug discovery, agents for chemotherapeutics and for monitoring of environmental contamination. In this paper, we present various methods which could by used for examination of the influence of different environmental chemicals and other xenobiotics on the immunocompetent cell activity in fish. The chemiluminescence response assay is important for study the phagocyte activity and the proliferative response assay of lymphocytes stimulated by mitogens is very important method for study the effects of xenobiotics on the lymphocyte $\mathrm{T}$ and $\mathrm{B}$ activities. We also demonstrate that in vitro immune response assay analyzed by PFC and ELISPOT are very sensitive techniques for studies of the effects of xenobiotics on the antibody secreting cells.
\end{abstract}

Fish, immunotoxicology, in vitro techniques

Information available on the role of the immunocompetent cells and immune mechanisms in the manifestation of toxicity by various chemicals is inadequate. More experimental studies need to be performed, particularly when the chemicals can produce allergic sensitization or may lead to autoimmune diseases. Immune suppression is sufficiently important to toxicology work and more studies relating dose and effect need to be performed by in vitro and in vivo examinations. The immunosuppressive potential of chemicals, especially environmental chemicals, are of great importance if the effects occur not only directly on the health. Predicting the immunotoxicological effects of chemicals requires more information. Defining the mechanisms of action, the structure-activity relationships and influence on the immunocompetent cells await additional data (Dunier and Siwicki 1993ab; Siwicki et al. 1990).

One of the most important directions in toxicology is in vitro immunotoxicological studies. Today many in vitro methods are very important in development of product, drug discovery, testing of chemotherapeutic agents and natural or synthetic immunomodulators and for monitoring of environmental contamination (Anderson et al. 1989; Anderson et al. 1986; Chan et al. 1991; Cossarini-Dunier et al. 1990; Dean 1972; Dunier et al. 1991; Elsasser et al. 1986: Fisher and Mueller 1981; Holsapple et al. 1986; Roux et al. 1979; Siwicki et al. 1989; Siwicki and Dunier 1994; Urban and Jarstrand 1986)

This article will review briefly the application of various in vitro methods to study the influence of different environmental chemicals and xenobiotics on the immunocompetent

Address for correspondence:

A. K. Siwicki

Department of Epizootiology with Clinic of Infections Diseoses

Faculty Veterinary Medicine

University in Olsztyn. Poland

Phone: +48895233574

Fax: +48895233328 
cells in fish - a very important aquatic bioindicator and model for experimental immunotoxicological investigation.

\section{Chemiluminescence assay (CL)}

The phenomenon of light emission or chemiluminescence $(\mathrm{CL})$ during phagocytosis was originally described by Allen et al. (1976). Bacteria and latex bead particles that were opsonized elicited CL when they were phagocytosed by polymorphonuclear (PMN) cells. Chemiluminescence, measured in a liquid scintillation counter operated in an out-ofcoincidence mode. was correlated with the number of cells, the concentration of the stimulus and the HMPS activity. Modification of the CL assay by addition of luminol, a cyclic hydrazide that can be oxidized to emit light, greatly amplified the sensitivity of the assay. Because the $\mathrm{CL}$ response represents the bactericidal mechanisms during the respiratory burst, it is widely used for studying phagocytosis. A correlation between the bactericidal activity and the CL response was shown by Welch (1980). Chemiluminescence has been demonstrated from phagocytes of different animals including humans, bovine, dogs, mice. rabbits, rats, pigs, fish and oyster.

Many substances elicit a CL response from phagocytes (Van Dyke 1987; Welch 1980; Wishkowsky et al. 1987; Zimmer and Jones 1990). The most common stimuli are zymosan, a yeast extract, latex beats, PMA, a soluble tumour-promoting compound, many bacteria and bacterial particles, and other soluble and insoluble activators ( $\mathrm{V}$ an Dyke 1987). The CL assay provides information regarding the health of an organism because the assay measures changes in phagocytosis, which affects the susceptibility of an individual to pathogenic agents. The most attractive features of the CL assay are objectivity, sensitivity, simplicity and rapidity.

Experiments to study the effect of environmental contaminants, chemicals and drugs on fish phagocytes have been carried out by applying the CL response. Wishkowsky et al. (1987) showed suppression of CL responses of phagocytes exposed to tetracycline in vitro. The oxytetracycline dosage recommended for aquaculture suppressed the CL by approximately $50 \%$. Elsasser et al. (1986) employed for the first time CL responses assay for in vitro study of the influence of heavy metals on phagocytosis in fish. Copper caused a decrease in the emission of the light to the baseline level. Aluminum also caused a partial suppression, whereas cadmium enhanced the CL response when added within $1 \mathrm{~h}$ prior to the assay or caused variable results after a $24 \mathrm{~h}$ exposure. Preliminary studies to compare the CL response of cells obtained from normal and pollutant-exposed fish exhibited a decrease in the response of the exposed fish (Warinner et al. 1988).

The CL responses assay were used for in vitro and in vivo studies of the effects of aquatic environmental contaminants on the phagocytic activity of polymorphonuclear (PMN) and mononuclear (MN) cells in fish (Dunier et al. 1994; Dunier et al. 1995).

\section{Lymphocyte proliferation assay (LP)}

The mechanisms for the immunotoxicity of heavy metals, pesticides and other xenobiotics are still debated owing to the fact that the numerous papers that previously dealt with this issue, frequently reported on in vitro examinations conducted with irrelevantly high concentrations. Therefore, future research efforts are still warranted to ascertain the in vivo relevance of these findings from a immunotoxicological point of view, with levels of exposure closer to those of environmental contamination. Because fish is one of the important bioindicators and frequently exposed to many pollutants in their aquatic environment, their immunocompetent cells may also become compromised by environmental contaminants. 
The influence of chemicals and other xenobiotics on the lymphocyte activity have been investigated in an in vitro study. The mitogen responses of lymphoid cells subpopulations demonstrated according to their selective responsiveness to different mitogens i.e. LPS (B lymphocyte mitogen) and ConA or PHA (T lymphocyte mitogens). Most proliferation assays were modified and adapted for in vitro studies. Du ni er et al. (1991) prepared in vitro protocol for study the effects of xenobiotics on proliferative response of lymphocytes in fish.

In vitro immune response assays

The in vitro techniques have many advantages for testing the effects of chemicals, pollutants and drugs on the cell-mediated immunity and specific immune response before more extensive in vivo examination is initiated.

The purpose of our studies was to investigate the possibilities of using in vitro assays to demonstrate the influence of environmental contamination on the nonspecific and specific immune responses. Many promising drugs have yet to be approved for use in humans and animals, and preliminary investigations might be used for screening in vitro. In addition, this is a promising techniques for studying the effects of pollutants and aquatic contaminants on the immune response in fish.

In immunotoxicological studies, two methods for determination of antibody secreting cells (ASC) are used: Passive Hemolytic Plaque assay (PHPA) and ELISPOT assay.

The passive haemolytic plaque assay is the most widely used test to assess antibodysecreting cells and to analyze the regulatory mechanisms of antibody production by B lymphocyte in fish. Jerne and Nordin (1963), the first to use the direct hemolytic plaque assays in mice injected with SRBC, were awarded the Nobel prize for developing this assay. In the test, the antibody-producing cells are held suspended in agar and centered in plaques or clear areas where the released antibody and complement have lysed the surrounding antigen-labeled red blood cells. Based upon these characteristics, the antibodyproducing cells (APC) are plaque-forming cells (PFC), and both those abbreviations are used interchangeably in the literature. This techniques has been used after in vitro immunization to compare bacterin doses (Anderson et al. 1986; Anderson et al. 1983; Siwicki et al. 1990) and to analyze the effects of chemicals, drugs and xenobiotics on the specific immune response mediated by several effector cells (Anderson et al. 1989; Anderson et al. 1989; Siwicki et al. 1989).

Recently, a new assay has been developed which utilizes solid-phase immunoenzyme technology and is named the ELISPOT assay (Siwicki and Dunier 1993; Siwicki et al. 1994). This assay can now be done in 96 well microtiter plates (25) enabling a large number of replicates to be performed and has recently been applied to in vitro and in vivo studies for quantification of antibody secreting cells after contamination by chemicals, drugs or xenobiotics. Dunier and Siwicki (1994) applied ELISPOT assay for immunotoxicological studies to quantify the total and specific ASC. The quantification of cells secreting specific antibody to pathogenic agents after incubation a cell suspension or organs (spleen, head kidney) with contaminants is possible with the ELISPOT assay. The use of the monoclonal anti-trout Ig or anti-carp Ig is well suitable and yields countable blue spots (Siwicki and Dunier 1993).

The development of the in vitro immunotoxicological assays is a very important part of monitoring of aquatic environmental contamination. Application of these methods has marked advantages over using in vivo models:

- fish requiring low water temperature are often more difficult to hold for long periods for testing effects of pollutants or drugs; the in vitro immunization models can be held optimally at $14{ }^{\circ} \mathrm{C}$ or at room temperatures,

- most experimental fish are not from inbred populations, therefore the immune response in highly variable among individuals. Replicate sections from the immunopoietic organs of the 
same animal, however, show more homogenous responses in vitro and differences due to immunomodulators can be indicated more accurately,

- timing of when the immune assay is done can be regulated in tissues from poikilothermic animals by temperature regulation. For instance, the assays could be delayed by holding the tissues at colder temperatures,

- fewer fish are used as the immunopoietic organs can be divided.

The comparative immunotoxicologists expect the in vitro immunization and other techniques for fish to become important in future fish toxicology studies as they are being developed for mammalian models. Holsapple et al. (1986) used immunopoietic cell suspension to study immunosuppression by dioxins; we have had less success using suspensions and have continued to use the organ section method. Differences in timing and doses of immunomodulators in relation to immunogens will require many experimental runs before these drugs and contaminants can be predictive of duplicating field situations, however, the applications and benefits of in vitro immunization assays are numerous.

\section{Imunotoxikologie in vitro - praktické využití}

Imunotoxikologie in vitro je jedním $\mathrm{z}$ nejdůležitějších směrů $\mathrm{v}$ imunotoxikologii. $\mathrm{V}$ současné době řada metod in vitro je použíána př́i posuzování nových léčiv, chemoterapeutik a při monitoringu zatižení životního prostředí. $V$ předkládané práci jsou prezentovány různé metody, které mohou být využity při sledování vlivu různých chemikálií a dalších xenobiotik na aktivitu imunokompetentních buněk u ryb. Chemoluminiscenční metoda je důležitá pro studium fagocytární aktivity a metoda využivající proliferaci lymfocytů stimulovaných mitogeny je velmi důležitá pro studium působení xenobiotik na $\mathrm{T}$ a $\mathrm{B}$ lymfocyty. Také je demonstrováno, že in vitro imunologické metody analyzované pomocí PFC a ELISPOT jsou velmi citlivými metodami pro studium působení xenobiotik na buňky produkující protilátky.

\section{References}

ALLEN, R. C., LOOSE. L. D. 1976: Phagocytic activation of a luminol-dependent chemiluminescence in rabbit alveolar and peritoneal macrophages. Biochem. Biophysic. Research Commun. 69: 245-252

ANDERSON, D. P.. DIXON, O., BODAMMER. J. E., LIZZIO E. F. 1989: Suppression of numbers of antibodyproducing cells from rainbow trout spleen organ section cultures exposed to copper in vitro. J. Aquat. Anim. Health 1: 174-189

ANDERSON, D. P., DIXON O., LIZZIO E. F.1986: Immunization and culture of rainbow trout organ sections in vitro. Vet. Immun. and Immunopath. 12: $203-211$

ANDERSON, D. P., MERCHANT, B., DIXON O., SCHOTT F. C., LIZZIO, E. F.1983: Flush exposure and injection immunization of rainbow trout to selected DNP conjugates. Devel. Comp. Immunol. 7: 261-268

ANDERSON, D. P., DIXON, O., SIWICKI, A. K. 1989: In vitro assays for chemicals and drug causing immunomodulation in fish. In Vitro Toxicology - New Directions. Mary Ann Liebert, Inc, New York 3: 237244

CHAN, P. C., HUFF, J., HASEMAN, J. K., ALISON, R., PREJEAN, J. D. 1991: Carcinogenesis studies of dichlorvos in fisher rats and B6C3F1 mice. Jpn. J. Cancer Res. 82: 157-165

COSSARINI-DUNIER, M., DEMAEL, A., SIWICKI, A. K. 1990: In vivo effect of the organophosphorus insecticide trichlorphon on the immune response of carp (Cyprinus carpio). I. Effect of contamination on antibody production in relation to residue level in organ. Ecotox. Environ. Safety 19: 93-98

DEAN, B. J. 1972: The effect of dichlorvos on cultured human lymphocytes. Arch. Toxicol. 30: 75-83.

DUNIER, M., SIWICKI. A. K., DEMAEL, A. 1991: In vivo effect of the organophosphorus insecticide trichlorphon on the immune response of carp (Cyprinus carpio). III. In vitro effects on lymphocyte proliferation and phagocytosis and in vivo effects on humoral response. Ecotox. Envir. Safety 22: 79-87

DUNIER, M., SIWICKI, A. K. 1993a : Effects of pesticides and other organic pollutants in the aquatic environment on immunity of fish: a review. Fish Shellfish Immunol. 3: 423-438

DUNIER, M., SIWICKI. A. K. 1993b: Study of effect of pollutants on fish defence mechanisms. I. In vitro 
influence of heavy metals on the spleen and kidney lymphocytes and macrophages activity in carp (Cyprinus (carpio). Fish Diseases Diagnosis and Prevention`s Methods. IFI Olsztyn: 69-79

DUNIER, M., SIWICKI. A. K. 1994: Effects of lindane on rainbow trout (Oncorhynchus mykiss) immunity. I. Effect of lindane on antibody-secreting cells (ASC) measured by ELISPOT assay. Ecotox. Environ. Safety 27: $1-6$

DUNIER, M., SIWICKI, A. K., SCHOLTENS, J., MOLIN, D. S., VERGNET, CH.. STUDNICKA M. 1994: Effects of lindane exposure on rainbow trout (Oncorhynchus mykiss) immunity. III. Effect on nonspecific immunity and B lymphocyte functions. Ecotox. Environ. Safety 27: 324 - 334.

DUNIER, M., VERGNET, CH., SIWICKI, A. K., VERLHAC, V. 1995: Effect of lindane exposure on rainbow trout (Oncorhynchus mykiss) immunity. IV. Prevention of nonspecific and specific immunosuppression by dietary vitamin C (Ascorbate-2-polyphosphate). Ecotox. Environ. Safety 30: 259-268

ELSASSER, M. S., ROBERTSON, B., HETRICK, F. M. 1986: Effects of metals on the chemiluminescent response of rainbow trout (Salmo gairdneri) phagocytes. Vet. Immunol. Immunopathol. 12: 243-250

FISHER, D. B., MUELLER, B. C. 1981: Gamma-hexachlorocyclohexane inhibits the initiation of lymphocyte growth by phytohemagglutinin. Biochem. Pharmacol. 20: 2515-2518

HOLSAPPLE, M. P., DOOLEY, R. K., MCNERNEY, P. J., MCCAY, J. C. 1986: Direct suppression of antibody response by chlorinated dibenzodioxins in cultured spleen cells from $(\mathrm{C} 57 \mathrm{BL} / 6 \times \mathrm{C} 3 \mathrm{H}) \mathrm{Fl}$ and DBA/2 Mice. Immunopharm. 12: 175-186

JERNE, N. K., NORDIN, A. A. 1963: Plaque formation in agar by single antibody-producing cells. Science 140: 405-407

ROUX, F., TREICH, I., DESOIZE, B., FOURNIER, E. 1979: Effect of lindane on human lymphocyte responses to phytohemagglutinin. Biochem. Pharmacol. 28: 2419-2426

SIWICKI, A. K., ANDERSON, D. P., DIXON, O. 1989: Comparisons of nonspecific and specific immunomodulation by oxolinic acid, oxytetracycline and levamisole in salmonids. Vet. Immunol. Immunopathol. 23: 195-200

SIWICKI. A. K., ANDERSON, D. P., DIXON O. 1990: In vitro immunostimulation of rainbow trout (Salmo gairdneri) spleen cells with levamisole. Develp. Comp. Immunol. 14: 231-237

SIWICKI, A. K., COSSARINI-DUNIER, M., STUDNICKA, M., DEMAEL, A. 1990: In vivo effect of the organophosphorus insecticide trichlorphon on the immune response of carp (Cyprinus carpio).II. Effect of high doses of trichlorphon on nonspecific immune response. Ecotox. Environ. Safety 19: 93-98

SIWICKI, A. K., DUNIER, M. 1993: Quantification of antibody secreting cells to Yersinia ruckeri by ELISPOT assay after in vivo and in vitro immunization of rainbow trout (Oncorhynchus mykiss). Vet. Immunol. Immunopathol. 37: 73-80

SIWICKI, A. K., DUNIER M. 1994: Effect of lindane exposure on rainbow trout (Oncorhynchus mykiss) immunity. II. In vitro restoration of antibody-secreting cells and lymphocyte proliferation activity by nitrogranulogen after in vivo immunosuppression due to lindane. Ecotox. Environ. Safety 27: 316-323

SIWICKI, A. K.. VERGNET, C., CHARLEMAGNE, J., DUNIER, M. 1994: Monoclonal antibodies against goldfish (Carassius aureatus) immunoglobulin: application to the quantification of immunoglobulin and antibody-secreting cells by ELISPOT and seric immunoglobulin and antibody levels by ELISA in carp (Cyprinus carpio). Vet. Res. 25: 458-467

URBAN, T., JARSTRAND, C. 1986: Selenium effects on human neutrophilic granulocyte function in vitro. Immunopharmacol. 12: 167-174

Van DYKE. K. 1987: Soluble and insoluble activators of neutrophil chemiluminescence. In: Cellular Chemiluminescence. Van Dyke and Castranova V. (Eds), CRC Press, Boca Raton. Florida: 161-172

WARINNER, J. E.. MATHEWS, E. S., WEEKS, B. A. 1988: Preliminary investigations of the chemiluminescent response in normal and pollutant-exposed fish. Marine Environ. Research 24: 281-284

WELCH. W. D. 1980: Correlation between measurements of the luminol-dependent chemiluminescence response and bacterial susceptibility to phagocytosis. Infection and Immunity 30: 370-374

WISHKOWSKY. A.. ROBERSON, B., HETRICK F. M. 1987: In vitro suppression of the phagocytic response of fish macrophages by tetracyclines. J. Fish Biol. 31: 61-65

ZIMMER. T., JONES, P. P. 1990: Combined effects of Tumor Necrosis Factor-alpha. Prostaglandin E-2 and Corticosterone on induced Ia expression on murine macrophages. J. Immunol. 145: 1167-1175 